\title{
Accounting for physicians' gender expectations improves men's health medicine
}

\author{
Emily Wentzell ${ }^{1}$ and Ajay Nangia ${ }^{2}$
}

Suggested citation Wentzell E, Nangia A. Accounting for physicians' gender expectations improves men's health medicine. Rev Panam Salud Publica. 2018;42:e103. https://doi.org/10.26633/RPSP.2018.103

ABSTRACT The field of men's health seeks to improve men's health outcomes by accounting for the specific ways that gender influences male health behaviors. To meet this goal, physicians must also account for the ways that their own cultural assumptions about masculinity influence their clinical practice. Gender is not solely biological. It is a way of acting out masculinity or femininity that varies across individual and cultural contexts. Thus, doctors and patients might have different ideas about how a man should feel and act. These attitudes can influence whether men's bodily changes are viewed as pathological versus normal. Two simple interventions are proposed to enable physicians to identify their own assumptions about masculinity and differentiate these from their patients' in order to make more appropriate treatment decisions. The first is advocating for medical guidelines for their specialty that account for gender as context-specific rather than universal. The second is incorporating attention to gender into their daily clinical practice by asking rather than assuming what patients want in order to base treatment decisions on patients' rather than physicians' ideas of how men should feel and behave.

Keywords Men's health; masculinity; interpersonal relations; United States.

\section{MASCULINITIES MATTER FOR MEN'S HEALTH}

A tenet of the emerging field of men's health is that gender matters in health care. For example, while women have been socialized into seeking out preventative care through behavior change interventions such as the "pink" campaign

Department of Anthropology, University of Iowa, Iowa City, Iowa, United States of America. Send correspondence to: Emily Wentzell, emily-wentzell@uiowa.edu

2 Department of Urology, University of Kansas Health System, Kansas City, Kansas, United States of America. for breast cancer awareness, men often avoid health care due to social expectations about male invulnerability. Men's health practitioners seek to address this gap. In this opinion and analysis piece, the authors argue that in addition to being aware of the effects of gender identity in their male patients' attitudes, lifestyle, and health, physicians must assess how their own ideas about masculinity influence their practice. To make this argument the authors 1) provide the social scientific definition of gender, 2) describe the limitations of considering the influence of patients' but not doctors' gender expectations in treatment interactions, and 3) draw on examples from their own research and practice to suggest remedies for such incomplete attention to gender in clinical practice.

Social scientists define gender as a cultural practice rather than a biological construct. According to this definition, attitudes about gender are the product of cultural expectations about how men or women should be. While biological attributes such as hormone levels do mediate individual feelings and attributes, the fact that ideals of masculinity and femininity vary so widely across place and 
time shows that gender is a learned, culturally specific trait rather than a universal, biological one. People learn to behave, as men or women, according to social expectations, without thinking about it-but it is a practice rather than a natural essence. Further, it is a fluid practice. Each person's expression of their gender reflects the diverse components of his/her identity, like religion, race, sexuality, or age, which can change over time and life experience. Individual expression of gender may also change within different contexts; for example, behavior related to individuals' perceptions of "being a man" may differ at work versus at home (1). Men's health practitioners aim to incorporate these insights into clinical practice to improve men's health outcomes. For example, cancer centers might modify media materials and clinical environments to attract men whose perception of masculinity as ideally tough and invulnerable might deter them from seeking care (2).

\section{DOCTORS' GENDER EXPECTATIONS INFLUENCE CARE}

Yet, analysis of the effect of gender norms on health care is often a one-way lens, turned only on patients. This limitation stems from the perception of medicine as a "culture of no culture" (3). Medical training includes a "hidden" or implicit curriculum that includes the view that medical practice is objective and not mediated by the specifics of a physician's identity (4). This can leave unchallenged dominant assumptions about gender and sexuality that influence many students' future medical practice (5). However, this idea is itself a cultural belief, specific to the culture of medicine, which belies the reality that all humans have unconscious biases shaped by their unique identities. Research shows that physicians' identities-gender, race, age, country of original training, etc.- do in fact influence their practice of medicine (6). This fact is only a problem if physicians do not recognize it. One must understand how identity affects one's actions in order to recognize and correct for the ways in which specific cultural attitudes might shape one's work, in order to try and maintain ethical decision-making. The authors of this article argue that responsive health care practice requires physicians to not only consider how their patients' gender matters, with regard to their health behavior, but also to evaluate how their own gender expectations influence their practice. Below, they discuss this issue and provide two interventions that physicians can make in order to account for their own gender ideologies in their medical practice: 1 ) advocating for guidelines that account for both health care provider and patient ideologies of gender, and 2) asking rather than assuming what patients want in order to base treatment decisions on patients' rather than physicians' ideas of how men should feel and behave.

Cultural ideas about how men should be, physically and socially, influence which bodily changes are seen as pathological and which are seen as variations of normal physiology. This cultural effect may not be apparent when ideas about masculinity embedded in common treatments match physicians' own ideas. For example, in Western societies, aging is often treated as a pathology rather than a natural process (7), and age-related decrease in the ability to have penetrative sex and do other "youthful" activities is often seen as a threat to the ability to demonstrate masculinity (8). For men with this ideology, conditions such as erectile dysfunction (ED) become a problem of gender. Drugs like Viagra thus offer biological cures to a fundamentally social problem-they serve as "masculinity pills" and are marketed as restorers of the youthful, virile masculinity that men are assumed to desire, and of the sexual penetration that all their partners are assumed to require $(9,10)$. As such, these treatments offer real help to patients who share these ideologies. If physicians understand that ED is a problem because it compromises some men's abilities to act out behavior they want to maintain due to their views about masculinity, they can offer appropriate treatment. But when physicians who share these views assume that they are universal, their ability to provide good care for all patients may be compromised. Patients might not share gender expectations that appear universal to physicians.

For example, social scientists have found that men from certain cultures or class positions may reject the idea that aging and decreased sexual function are social or biological problems. They instead understand respectable aging to require demonstrating socially appropriate behavioral change over time (11-14). For example, anthropological research by the lead author of this article (EW) with older, working-class Mexican men revealed that most saw decreased erectile function as a "normal" change rather than a pathology. These men were raised to be "macho," then left feeling outmoded when times changed and intimate, faithful, and domestically oriented masculinity became ideal. They saw having decreased erectile function as a reprieve from sexual urges, which then enabled them to change their behavior and act like respectable older men. Both they and their partners saw shifting emphasis away from penetrative sex toward emotional engagement with family as a positive change, facilitated by men's aging bodies (15). It is important for physicians to understand when their own understandings of masculinity lead them to assume that a change in sexual function is pathological, so that they can then assess whether or not-rather than assume that-it is a problem for their patient.

This example shows how patients and physicians might differently understand how men's sexual practice should change as they age. Similarly, doctors and patients might think differently about how men's bodies should work based on all other aspects of identity, such as class, race, sexuality, or religion. As the above example shows, such ideals might also change over the course of one's own life. Thus, analyzing one's own current gender ideology is necessary for appropriately treating patients.

For instance, identifying their own assumptions about gender can also help physicians apply medical guidelines more appropriately. For example, ED is medically defined as "the persistent inability to achieve or maintain an erection sufficient for satisfactory sexual performance" (16: 141). The use of the open-ended terms "sufficient" and "satisfactory" in this definition account for the fact that people hold varying ideas about what kinds of sex are manly and age-appropriate. However, medical researchers who assume men should want to have penetrative sex throughout the life course often define any quantitative decrease in erectile function as dysfunction. This assumption can misdirect treatment from patients' lived needs. These needs can include sexual desire met through non-penetrative activities. 
They can also include reduction of sex. EW's research in Mexico shows that while decreased erectile function is common in older, working-class men, seeing it as a problem is not. Thus, interpreting decreased erectile function as ED in this population would lead to overmedication and waste of the public health system's limited resources, with negative consequences for men who believed that decreasing erectile function facilitated positive social change (17).

The second author of this article (AN) has observed the variation in patients' ideas about masculinity in his U.S.-based urology practice. It might be assumed that, based on certain stereotypes in U.S. culture, men would view infertility as a threat to their manhood, with manliness defined by virility. While this is true for some male patients, AN has also treated men who demonstrated that their ideal of masculinity involved supporting the emotional health of their partner related to their ability to conceive. These men were seeking fertility treatment due to feelings of guilt that their partners were not able to have a child, and they wanted to engage in medical treatment as actively as possible to show that they were doing all that they could. AN recalls one patient with a sperm-production problem asking, "What can I do to help myself? Can I make it better? Sleep differently, eat better, lose weight, meditate?" Physicians can draw on this view of masculine roles and responsibilities to promote preventative health behavior related to fertility, and in referring patients to psychological support for coping with the emotional toll of wanting to, but fearing failure at, supporting one's spouse emotionally and reproductively. The possibilities and pitfalls in health care for men with these types of perceptions about masculinity are quite different from those for men who joke to AN about "shooting blanks" and seek to avoid medical intervention due to their ideas that men should be invulnerable. Providing care that accounts for these differences requires physicians to realize that their own assumptions about how men should "be," and feel, are not universal.

\section{WHAT TO DO?}

The authors of this article recognize that physicians are rarely trained in gender studies and have limited time, both in clinical interactions and for their own continuing education, to learn about gender issues. Fortunately, physicians can make their practice sensitive to diversity in gender norms by engaging in self-reflection followed by two basic actions. One is at the level of their medical specialty, and the other is an act to incorporate into their daily practice. Both require physicians to first understand that their own expectations for masculinity are culturally specific rather than universal, and might or might not match an individual patient's beliefs about or experiences of gender.

The first intervention is to advocate for medical guidelines that account for gender as a context-specific practice, rather than a universal biological essence. Medical guidelines on sexual function and aging often pay lip service to psychosocial issues while reflecting the authors' cultural assumptions about what is normal versus pathological. For example, European guidelines on assessing $\mathrm{ED}$ and premature ejaculation (PE) include a flowchart that includes a step for "assess[ing] psychosocial status" that leads only to biological intervention (18). The rate at which men discontinue their ED medication demonstrates that this emphasis on a one-size-fits-all medical approach to decreased erectile function is not meeting all patients' needs (19). Physicians who understand what their own ideals of masculinity are will be able to assess whether those ideals are taken for granted in, or omitted from, medical guidelines. Understanding how guidelines reflect cultural assumptions about gender will enable physicians to apply them in a more nuanced way that accounts for patients' own ideals of masculinity. Even better, physicians who understand that peoples' ideals of masculinity differ can create guidelines that emphasize the interpersonal, social, and context-specific nature of ideas like sexual dysfunction. Such guidelines can incorporate rather than gloss over the differences in the kinds of sexuality and physical aging that varied patients might see as supporting or threatening their masculinity, however it is perceived.

The second intervention is a clinical one. It requires asking, rather than assuming, what patients want. Rather than following their own gender expectations and assuming that a patient will view a particular physical change as a problem, or what the emotional effect of a diagnosis might be, physicians should recognize that expectations and ideas about masculinity differ. Understanding their own views as culturally specific rather than universal enables physicians to identify cases where patients' gender ideologies might require different care than what the clinicians themselves would desire. Instead of making assumptions based on their own gender norms-or on those often implicit in medical guidelinesdoctors can provide more appropriate treatment by enabling patients to tell them which bodily changes pose what social problems. AN accomplishes this by simply asking patients "What's bothering you?" or saying "Tell me how you feel."

Basing one's clinical response on the patients' stated needs rather than the physicians' assumptions about what men should want enables patients to feel more comfortable and better understood, which in turn facilitates discussion of their health problems. This approach should also inform the physicians' response and in some cases their decisions about treatment. For example, a varicocele might require surgical correction, if it impedes desired fertility, but it might not require surgery if the patient does not wish to have children. In cases like cancer diagnoses, AN couples medical treatments with explanations and referrals for emotional support tailored to patients' individual hopes for the areas of life their treatment might affect, such as reproductive goals.

\section{CONCLUSIONS}

Physicians can enhance their practice by recognizing that neither their own expectations about masculinity nor those assumed in medical guidelines are universal. By identifying their and their fields' assumptions about gender, they can see where these diverge from patients' own understandings, and thus treat men's actual rather than assumed needs. Crafting treatment plans that account for how physical problems and changes affect men's perceptions of their own masculinity can thus lead to more appropriate and effective use of resources in national health systems by treating only the changes that men actually perceive as problematic. Accounting for the diversity in gender ideals in men's health treatment can also avoid reinforcing stereotypes of masculinity within medical treatment. Avoiding this 
can foster positive social change-away from simplistic assumptions of men as obsessed with virility and toughnessthat can in turn have the positive health benefits of encouraging ideas about masculinity that focus on caring for self and others. Operationalizing this kind of

1. Kimmel MS. The gendered society. $1^{\text {st }}$ ed. New York: Oxford University Press; 2000.

2. El-Manstrly D, Rosenbaum MS. Encouraging male participation in cancer resource centers. Serv Ind J. 2018;38(1-2):114-26. doi: 10.1080/02642069.2017.1402008.

3. Taylor JS, Wendland C. The hidden curriculum in medicine's "culture of no culture." In: Hafferty FW, O'Donnell JF. The hidden curriculum in health professional education. Hanover, NH: Dartmouth College Press; 2015.

4. Bandini J, Mitchell C, Epstein-Peterson ZD, Amobi A, Cahill J, Peteet J, et al. Student and faculty reflections of the hidden curriculum. Am J Hosp Palliat Care. 2017;34(1):5763. doi: 10.1177/1049909115616359.

5. Cheng LF, Yang HC. Learning about gender on campus: an analysis of the hidden curriculum for medical students. Med Educ. 2015;49(3):321-31. doi: 10.1111/ medu. 12628.

6. James SA. The strangest of all encounters: racial and ethnic discrimination in US health care. Cad Saude Publica. 2017;33 (Suppl 1):e00104416. doi: 10.1590/0102311X00104416.

7. Lamb S, editor. Successful aging as a contemporary obsession: global perspectives. New Brunswick, NJ: Rutgers University Press; 2017.

8. Tyler A, Nodin N, Peel E, Rivers I. "I am getting old and that takes some getting used to": dimensions of body image change in clinical practice will mean more appropriate and personalized patient care, which in turn will encourage men in their diversity to make more use of health care resources.

\section{Conflicts of interest. None.}

\section{REFERENCES}

for older men. In: Peel E, Harding R, editors. Ageing and sexualities: interdisciplinary perspectives. London: Routledge; 2017.

9. Loe M. The rise of Viagra: how the little blue pill changed sex in America. New York: New York University Press; 2004.

10. Camoletto RF, Bertone C. Medicalized virilism under scrutiny: expert knowledge on male sexual health in Italy. In: King A, Santos AC, Crowhurst I, editors. Sexualities research: critical interjections, diverse methodologies, and practical applications. New York: Routledge; 2017.

11. van der Geest S. "No strength": sex and old age in a rural town in Ghana. Soc Sci Med. 2001;53(10):1383-96. doi: 10.1016/ S0277-9536(01)00222-2.

12. Camoletto RF, Bertone C. Italians (should) do it better? Medicalisation and the disempowering of intimacy. Mod Italy. 2012;17 (4):433-48. doi: 10.1080/13532944.2012. 706996.

13. Potts A, Grace V, Gavey N, Vares T. "Viagra stories": challenging 'erectile dysfunction.' Soc Sci Med. 2004;59(3):489-99. doi: 10.1016/j.socscimed.2003.06.001.

14. Sandberg L. Just feeling a naked body close to you: men, sexuality and intimacy in later life. Sexualities. 2013;16(3-4): 261-82. doi: 10.1177/1363460713481726.

15. Wentzell EA. Maturing masculinities: aging, chronic illness, and Viagra in
Disclaimer. Authors hold sole responsibility for the views expressed in the manuscript, which may not necessarily reflect the opinion or policy of the RPSP/ PAJPH or the Pan American Health Organization (PAHO).

Mexico. Durham, NC: Duke University Press; 2013.

16. Lizza EF, Rosen R. Definition and classification of erectile dysfunction: report of the Nomenclature Committee of the International Society of Impotence Research. Int J Impot Res. 1999;11(3):141-3.

17. Wentzell E, Salmerón J. Prevalence of erectile dysfunction and its treatment in a Mexican population: distinguishing between erectile function change and dysfunction. J Men's Health. 2009;6(1):56-62. doi: 10.1016/j.jomh.2008.09.009.

18. Hatzimouratidis K, Amar E, Eardley I, Giuliano F, Hatzichristou D, Montorsi F, et al. Guidelines on male sexual dysfunction: erectile dysfunction and premature ejaculation. Eur Urol. 2010;57(5):804-14. doi: 10.1016/j.eururo.2010.02.020.

19. Carvalheira AA, Pereira NM, Maroco J, Forjaz V. Dropout in the treatment of erectile dysfunction with PDE5: a study on predictors and a qualitative analysis of reasons for discontinuation. J Sex Med. 2012;9(9):2361-9. doi: 10.1111/j.1743-6109. 2012.02787.x.

Manuscript submitted 18 October 2017. Revised version accepted for publication on 19 April 2018. 
RESUMEN El campo de la salud masculina procura mejorar los resultados en materia de salud de los hombres al reconocer las maneras específicas en que el género influye en el comportamiento de los hombres con respecto a la salud. Para alcanzar esta meta, los médi-

Tener en cuenta las expectativas de los médicos respecto al género mejora la atención de salud de los hombres

\author{
Palabras clave
}

cos también deben tener en cuenta la manera en que sus propios supuestos culturales acerca de la masculinidad influyen en su práctica clínica. El género no es solo biológico; es una manera de exteriorizar la masculinidad o la femineidad que varía entre los diversos contextos individuales y culturales. Por consiguiente, los médicos y los pacientes pueden tener ideas diferentes acerca de cómo debe sentirse y actuar un hombre, y estas actitudes pueden influir en que los cambios físicos de los hombres se perciban como patológicos o como normales. Se proponen dos intervenciones sencillas para ayudar a los médicos a tomar consciencia de sus propios supuestos acerca de la masculinidad y distinguirlos de los de sus pacientes, a fin de tomar decisiones terapéuticas más apropiadas. La primera intervención consiste en promover pautas clínicas para su especialidad que reconozcan el género como algo dependiente del contexto en lugar de algo universal. La segunda es incorporar la atención al género en su práctica clínica diaria al preguntar a los pacientes qué desean en lugar de suponerlo, a fin de basar las decisiones terapéuticas en las ideas de los pacientes sobre cómo deben sentirse y comportarse los hombres, en lugar de las ideas del médico.

Salud del hombre; masculinidad; relaciones interpersonales; Estados Unidos.

RESUMO O ramo da saúde masculina procura melhorar os desfechos de saúde do homem ao levar em consideração as maneiras inerentes como o gênero influencia os comportamentos masculinos com relação à saúde. Para esta finalidade, os médicos também

\section{Levar em consideração as expectativas de gênero dos médicos melhora a atenção da saúde masculina} devem levar em conta que seus próprios pressupostos culturais sobre masculinidade influenciam a prática clínica. O gênero não é meramente um aspecto biológico. É uma forma de exteriorizar a masculinidade ou a feminilidade que varia dependendo do contexto individual e cultural. Assim, médicos e pacientes podem ter noções distintas sobre como um homem deve se sentir e agir e estas atitudes podem influir na maneira como são consideradas as mudanças físicas no corpo de um homem, se patológicas ou normais. São propostas duas intervenções simples para ajudar os médicos a se conscientizarem dos próprios pressupostos sobre masculinidade e diferenciá-los dos pressupostos dos pacientes a fim de que possam tomar decisões de tratamento mais apropriadas. A primeira intervenção consiste em defender orientações médicas para a especialidade que reconheçam o gênero como próprio para um contexto, em vez de algo universal. A segunda consiste em incorporar a atenção ao gênero à prática clínica diária, perguntando ao paciente o que ele quer, em vez de fazer suposições, a fim de fundar as decisões de tratamento nas noções do paciente, não nas do médico, de como um homem deve se sentir e se comportar.

Palavras-chave Saúde do homem; masculinidade; relações interpessoais; Estados Unidos. 